\title{
Rethinking "energy nationalism": a study of the relationship between nation states and companies in the oil industry
}

\author{
NOELE DE FREITAS PEIGO \\ JOSÉ AUGUSTO GASPAR RUAS
}

\begin{abstract}
RESUMO: O termo “nacionalismo energético" é frequentemente utilizado pela literatura e mídia acadêmicas, mas geralmente sem precisão conceitual adequada. Apesar disso, um conjunto de artigos aprofunda a discussão sobre a relação entre estados nacionais e a indústria energética, especialmente o setor de petróleo. Estes artigos permitem identificar elementos fundamentais para entender o nacionalismo energético, seja complementar ou divergente entre si. Este estudo tem por objetivo apresentar uma interpretação do conceito que preenche as lacunas deixadas pela literatura acima indicada com base numa análise global da estrutura da indústria do petróleo e da sua evolução histórica desde meados do século 19.

PALAVRAS-CHAVE: nacionalismo energético; petróleo; as reservas; a indústria do petróleo; a economia política da energia.
\end{abstract}

ABSTRACT: The term "energy nationalism" is frequently used by academic literature and media, but usually without adequate conceptual accuracy. Despite this, a set of papers deepens the discussion on the relationship between nation states and the energy industry, especially the oil sector. These papers allow identifying fundamental elements to understand the energy nationalism, either complementary or divergent between each other. Thus, this study aims at presenting an interpretation of the concept that fills the gaps left by the above mentioned literature based on a global analysis of the oil industry structure and its historical evolution since the mid-19 $9^{\text {th }}$ century.

KEYWORDS: energy nationalism; oil reserves; oil industry; political economy of energy. JEL Classification: F52; L71; Q34; Q43.

\footnotetext{
* Respectivamente, Economista e Analista de Relações Internacionais, mestranda MBP (Master Business Petroleum) na COPPE - UFRJ (RJ). E-mail: noeledefreitas@gmail.com-Brasil; Economista,Professor e Coordenador Adjunto do Curso de Economia na Facamp. E-mail: joseaugusto.ruas@facamp.com - Brasil.br. Submetido: 31/março/2014; Aprovado: 7/julho/2014.
} 


\section{INTRODUCTION}

Although a recurrent issue in the political-economic debate, in general the term "energy nationalism" has not been properly dealt with. The term, which reflects the relationship between nation states and energy companies, is traditionally employed to criticize the use of control instruments over energetic resources. Under this prism, the intervention of the producing states é characterized as unwanted, and as an obstacle to investment and the efficient working of the markets.

The variety of relationships and interests involved in the establishment and historical development of the energy industry makes the above-mentioned argument insufficient, at least. In order to broaden the understanding of some of the dimensions of this industry, this article presents elements for a new approach to energy nationalism. Thus, it proposes an analysis of the term focusing on the oil industry, one of the most important and internationally disputed sectors.

Generally, the building up of such approach is based on two contributions. Firstly, the revaluation of the importance of players normally neglected by the main traditional approaches: the nation states of consuming countries and the state owned and the semi-state owned companies. Secondly, the definition of political and institutional arrangements of the oil industry in its various historical contexts, as well as the investigation of the reasons for its typically cyclical behavior.

The article is divided in two sections: the first presents a literature review about the concept of "energy nationalism" in distinct academic perspectives aiming at identifying virtues and gaps in their approaches. The second section incorporates elements to consider the relationship between the nation states and the oil companies based on a historical-structural analysis of this world industry. Lastly, the final considerations systematize the elements discussed throughout the article, presenting an alternative interpretation about energy nationalism.

\section{"ENERGY NATIONALISM": THE RECURRING APPROACH IN THE LITERATURE OF THE ECONOMICS OF ENERGY}

The expression energy nationalism is broadly used in the academic literature and in the specialized media of the industry, and may mobilize distinct political interests in almost all countries, weather they are oil producers or not. Most of the time, the term is used in critical arguments against the policy of oil reserve owners or in favor of the supposed superiority of free market trading. Thus presented, it constitutes an ahistorical opinion about the institutional ways and proper instruments to rule the relationship between the state nations and the companies. Such interpretations, however, are not homogeneous and deserve careful analysis.

A traditional view of the subject discusses energy nationalism from the perspective of economic orthodoxy, based of the premise that state intervention in the functioning of the markets always causes losses of economic efficiency and well being. In this sense, Armentano (1981) advocates that the world oil industry, in its genesis (1846-1911), represents an "example of a competitive and free market", 
with low governmental regulation (absence of price controls, restrictions to entrance, tariffs, quotas or controls over allocation). For him, this structure was responsible for its "phenomenal growth and development" (Armentano, 1981, p. 76). However, for this author, after the strengthening of regulation during later decades, the oil market became inefficient.

Other approaches on energy nationalism share concerns about the role of the state in leading the energy industry, although they do not reconstruct, like Armentano (1981), the mainstream liberal economic argument. Generally, these studies emphasize the inefficiencies caused by the disarrangement or legal instability of the producing countries, reinforcing the risks of reduction in investment as well as in the global supply of energy.

Barbieri's study (2011) considers the subject accordingly. Through her analysis of the political actions of South Korea in Latin America (thus, based on the point of view of a consuming country), the author considers energy nationalism as a sort of "energetic diplomacy". It is exemplified by the setting of partnerships to grant access to energetic sources, by emphasizing interchange programs, the establishment of research institutes and diplomatic meetings. In this sense, the "energetic diplomacy" would be responsible for leading the corresponding negotiations between nation states and oil companies (state-owned, partly state-owned and private), aiming at determining which instruments will be used to put the energetic policy in practice.

A key issue for this author - as well as in other approaches that deal with the intervention of producing states under the point of view of the consuming countries - is granting access to energy, thus having in mind the domestic energy security. Whenever her work focuses on the strengthening of national oil companies, especially in Latin America, the "nationalism of resources" is presented as an increase in state control - with a negative emphasis on Mexico, Venezuela, Argentina, Bolivia and Ecuador (Barbieri, 2011). On the other hand, led by Brazil, Colombia and Peru, the opening to foreign capital and the promotion of regulated competition are presented as virtuous. This same differentiation may be found in Isbell's analysis (2009), which also includes Chile as a case where there was a "legitimate state role" and market orientation.

It is still noteworthy that Barbieri (2011) shows that the energetic sector is generally characterized by governmental intervention, either in the form of support to national enterprises or of control over private companies, due to the importance of energy sources for the development of countries. Accordingly, the producing nation states exercise their energy nationalism as a reaction to the neoliberal recipe and as a means to protect their resources (Barbieri, 2011). Such assessment sets this author apart from the followers of the classic orthodox theory and the supporters of the free market as the only and best solution. Yet, in her analysis the state intervention may represent a threat to global energetic security by limiting the industry supply, while discouraging or even stopping investments.

By pointing to the fact that there will be an increase in global demand for energy and that the resources are unevenly distributed throughout the world, Barbieri (2011) even considers the distinct performance by countries "short in resources". Despite this finding, she does not analyze its repercussion for the building of a broader concept of "energy nationalism" that would consider the importance 
of the consuming nation states in the configuration of the historical forces that constitute the industry.

Such distinction between consuming and producing countries shows up more clearly in the work of Mabro (2007). According to him, the "oil nationalism" may be considered "a generic label that hides (due to its generalization) more than it reveals" (Mabro, 2007, p. 4). Thus, despite of what it looks like, governmental intervention in the oil industry is not an exclusive prerogative of Third World producing countries. The author even mentions the fact that in the 1920s, European countries like France, Spain and Italy have also established their national oil companies. Notwithstanding this important consideration, Mabro (2007) restricts his analysis only to the producing countries, using the examples of Venezuela, Bolivia and Russia.

Considering that the relationship between hosting governments and international oil companies has always been uncertain, given the chance that expropriation and unilateral changes in agreed upon contracts has always been present in the oil industry, Mabro (2007) points out to the possible causes of "oil nationalism": (1) the mistrust of developing countries towards foreign powers, deemed imperialistic; (2) the importance of the oil as the main, and sometimes the only, available resource for a Third World exporting country; and (3) the occasional friction concerning oil companies and contracts, which may become unfavorable to any of the parts involved due to historical changes.

Thus, besides considering the market inefficiencies (contract frictions) and the disparities caused by the unbalance in economic and political power among the players involved in the negotiations, the author also considers in his analysis the changes that arise from historical factors, a category that is hardly compatible with the approaches based on the efficiency of market allocations.

The author also highlights the link between oil nationalism both in producing and consuming countries. While in the former prevails the view that the oil - commonly their most valuable economic asset that should not be left to foreigners - in the latter, the oil is considered a strategic commodity, thus justifying any political interference aiming at preserving national interests.

Another work that deals with the subject of energy nationalism is the one by Stevens (2008), which offers a further contribution to the analysis of the relationship between nation states and oil companies in the long run. By presenting an investigation of nationalistic cycles, it shows alternating fundamental drivers as a set of exogenous and endogenous factors to the oil and gas industry. Such factors could explain the transformation in the "bargaining power" of countries and companies as changing, in various historical periods, the power relations of the industry:

"Resource nationalism" is assumed to have two components - limiting the operations of private international oil companies (IOCs) and asserting a greater national control over natural resource development. This phenomenon has had a long history and not just in the context of oil or minerals [...] However, there is also an ideological component to "resource nationalism" strongly linked to the perceived role of the state in the operation of the national economy, and it is this that contributes a cyclical appearance to the phenomenon. (Stevens, 2008, pp. 5-6). 
According to this definition, the exogenous factors are considered the ideological elements that, in each historical moment, support or condemn state intervention in the economy. According to him, these elements may be influenced by the behavior of the dominant classes due to their ability to impose ideologies, but also due to the reactions to the implemented policies. As a rule of thumb, such changes would directly affect the political interests because of the presence of foreign companies in national territory, especially in such a strategic industry as oil.

The endogenous factors, on the other hand, cover various elements, among which is the state of "bargaining obsolescence" due to its own natural cycle, as well as the need by producing countries of capital, technology and markets granted by private companies. Such needs are changed by the level of oil prices, by the competitive level at the moment of the signing of agreements, by the sophistication of the players involved, and by the geology of the region (Stevens, 2008).

Thus, Stevens (2008) indicates that the endogenous and exogenous factors are capable of influencing the historical cycles of the global oil industry, pushing for a stronger or weaker role of the "resource nationalism." For him, the cycles fuel each other: a period of energy nationalism would necessarily lead to lower investments, thus to oil shortage, then to price increases. However, the author acknowledges that markets work imperfectly, so that this situation would provoke changes in supply and demand, causing a drop in prices. With a higher need of capital and technology, the energy nationalism would recede, and so forth.

The mechanistic cycle view deserves a broader set of criticism. An analysis of the $21^{\text {st }}$ century shows that price movements are not in direct proportion to the physical supply and demand of oil, subject to a strong influence from speculation in future markets. Additionally, this same historical moment shows the possibility of long periods of coexistence of growing demand and higher prices. Even though it presents a backlash in various analytical aspects whenever compared to Mabro's (2007), Stevens' approach (2008) points to a relative institutional flexibility, strongly in line with the industry's history, and important to the analysis of energy nationalism.

A relatively similar assessment is found in Newbery (1999). For this author, who broadly considers the infrastructure industries, the institutions should not be regarded as ahistorical elements - apart from the cultural and political transformation of each country or region - or as changes in the balance of the political power, in the relative power of interested parties, in technology, in the international competitive pressure or in the needs of investment.

For this analysis, it is also evident that the regulatory marks in the energy industry should be considered unstable. This does not mean that important historical experiences were not based on legal-political regularities. It only means that the energy industry, in its long evolution over time, presents changes in the relationships between nation states and companies that reflect and make compatible the structural modifications in the potentialities and longings of each of the involved players.

Table 1 summarizes the findings in the referred literature so far: 
Table 1: Energy economics literature about "energy nationalism"

\begin{tabular}{|c|c|c|}
\hline Authors & Contributions & Inadequacies and/or gaps \\
\hline $\begin{array}{l}\text { Armentano } \\
\text { (1981) }\end{array}$ & - & $\begin{array}{l}\text { - State intervention in the functioning } \\
\text { of the market always causes losses in } \\
\text { economic efficiency and well being. }\end{array}$ \\
\hline $\begin{array}{l}\text { Barbieri } \\
\text { (2011) }\end{array}$ & $\begin{array}{l}\text { - Resources are unevenly distributed } \\
\text { throughout the world; } \\
\text { - Energetic policy is seen according to } \\
\text { the perspective of the consuming nation } \\
\text { states: the guarantee of energetic } \\
\text { security; } \\
\text { - The behavior of the producing nation } \\
\text { states is a response to the neoliberal } \\
\text { recipe and a way to protect their } \\
\text { resources. }\end{array}$ & $\begin{array}{l}\text { - Distinctions in the exercise of "resource } \\
\text { nationalism" by groups of countries } \\
\text { (positive and negative assessment); } \\
\text { - State intervention may represent a } \\
\text { threat; } \\
\text { - Does not analyze the implications of } \\
\text { the consuming countries behavior upon } \\
\text { "energy nationalism". }\end{array}$ \\
\hline Isbell (2009) & - & $\begin{array}{l}\text { - Distinctions about the exercise } \\
\text { of "energy nationalism" by groups } \\
\text { of countries (restrictive/negative for } \\
\text { companies and more open and oriented } \\
\text { by the market/positive). }\end{array}$ \\
\hline $\begin{array}{l}\text { Mabro } \\
(2007)\end{array}$ & $\begin{array}{l}\text { - Government intervention in the oil } \\
\text { industry is not an exclusive prerogative of } \\
\text { producing countries; } \\
\text { - Causes of "oil nationalism"; } \\
\text { - Takes in consideration market } \\
\text { inefficiencies (contractual friction) and } \\
\text { differences caused by the heterogeneity } \\
\text { of economic and political power among } \\
\text { the players involved in the negotiations; } \\
\text { - Takes in consideration the changes } \\
\text { resulting from historical factors. }\end{array}$ & - \\
\hline $\begin{array}{l}\text { Stevens } \\
(2008)\end{array}$ & $\begin{array}{l}\text { - Analysis of nationalistic cycles: set of } \\
\text { industry's endogenous and exogenous } \\
\text { factors; } \\
\text { - Existence of "bargaining power"; } \\
\text { - Institutional flexibility. }\end{array}$ & $\begin{array}{l}\text { - Does not clearly show the possibility } \\
\text { that producing and consuming countries } \\
\text { may have on energy nationalism; } \\
\text { - Predominantly conservative character: } \\
\text { intervention policies by producing } \\
\text { countries are inadequate and a } \\
\text { supposedly natural and mechanistic } \\
\text { movement of the energetic nationalist } \\
\text { cycles. }\end{array}$ \\
\hline $\begin{array}{l}\text { Newbery } \\
\text { (1999) }\end{array}$ & - Institutional flexibility. & \\
\hline
\end{tabular}

Source: Own elaboration based on analysis and systematization of the indicated literature. 
Although based on different points of view, each of the listed interpretations points to different dimensions of the inadequacy of the liberal understanding about the relationship between nation states and oil companies. The existence of market failures, the possibility of institutional instabilities, the importance of the consuming countries' policies, the possibility of changes in the power relations among players, and of cycles of intervention in the energy industry are key elements to perfect the concept of energy nationalism already existing in the traditional literature about it.

Additionally, even with such considerations, it is neither clear what is the role of consuming nation states in exercising the so-called energy nationalism, nor the importance of changes in the dynamics of competition within the industry, or the role of state-owned companies. In this sense, the second section presents a broader analysis about the elements that compose and influence energy nationalism, contemplating the issues left unsolved by the authors studied, then proposing an allencompassing concept that allows mediations in the analysis of distinct historical scenarios.

\section{ENERGY NATIONALISM AND POLITICAL ECONOMY: AN INTERPRETATION BASED ON THE STRUCTURAL HISTORICAL ANALYSIS OF THE OIL INDUSTRY}

As already emphasized in the first section, the discussion about energy nationalism should not occur as a theoretical inference based on economic models. Instead, it can only take place under the light of its historical characteristics, as a result of the evolution of the relationship among the economic players involved in its operation. Thus, we have to understand the nature of the industry and its transforming structures over time.

Certainly, such investigation is based on the importance the oil industry assumed throughout the $20^{\text {th }}$ century, during which it became indispensable for economic development. In this process, which began in the $20^{\text {th }}$ century, the strategies of national development and private accumulation (including the state-owned companies) evolved to establish production mechanisms, and the appropriation and use of such wealth. In other words, the history of the industry may be characterized by the transformations within the intricate web of relations - and political and economic dispute - involving companies (private and national) and nation states (producers and consumers) aiming at guaranteeing an adequate supply of energy to the countries, and the control of the spaces of valuation and appropriation of the wealth produced in the sector.

In this web, the structures and institutions, including the national regulatory frameworks, are determined by the historical evolution of the characteristics that grant power to the aforementioned nation states and companies. This "political game", which in the beginning of the $20^{\text {th }}$ century was based on the internal issues particularly associated with the United States, broadened its reach and became a complex global geopolitical network. Such network is influenced by factors exog- 
enous to the industry (geopolitical and geo-economic trends), but also by its endogenous factors (oil price levels together with the control of natural resources and capital reserves, as well as the investment capabilities of each economy and its companies).

If done under this prism, the characterization of energy nationalism in the oil industry may be seen according to a new perspective, which allows the understanding of its different historical morphology, and its unquestionable relation to the economic and political cycles of the industry.

\section{Oil industry: historical evolution and structural determinants}

A first challenge to the investigation of energy nationalism in the oil industry may be found in the understanding of oil as a special commodity, which production and consumption mold power structures distinct from other commodities. Such characterization is associated with a set of factors, among which are the military, economic and social importance, together with the historical developments of the relations of this industry and the constitutions of its structural elements.

The first dimension that is clear is the political-military importance of oil. The "pioneering" of such sphere may be found in the discovery of its efficiency in the transportation of troops and in military power, based on the innovations of the Second Industrial Revolution. Crucial during the two world wars, they consolidated the strategic interest for the fuel by the Armed Forces (Yergin, 1991; Hobsbawm, 1994; Torres Filho, 2004). Since then, the control of its sources engendered battles and the geographical reorganization of military interests, influencing diplomatic and colonialist projects during the following years, when the speculation about its future shortage became a concern, especially for the USA.

Besides its military importance, the relevance of oil to the organization of a social life standard - for the people and the industrial complex - consolidated after the 1950s with a "great change in the energetic paradigm" (Torres Filho, 2004, p. 313). In this process, oil increasingly became the main source of primary energy of the global energy matrix.

The reasons for the vital socioeconomic importance of oil after World War II are diverse. Firstly, there is its role as driver for the industrial complex, either as raw material and/or energy source for various industries, or as fuel for transportation. Again, oil gets a growing importance with the emergence of multiple applications associated to innovations of the Second Industrial Revolution: the new forms of industrial organization (like "Taylorism" or "Fordism"), urbanization and the spreading of new transportation means (automobiles), lighting, as well as a myriad of chemicals and derivates that followed, like plastics (Torres Filho, 2004).

Accordingly, the advancement of the oil industry is associated to what Yergin (1991) called the Hydrocarbon Man society. The "hydrocarbon man" society meant the mass spreading of the oil use, around which society was molded. There was a historical transformation from the typical society of the beginning of the $19^{\text {th }}$ century to the modernity of the industrial and urban societies, having impacts on 
political and economic relations, both internal and external, with the consolidation of the sovereignty of oil as a vital element to the maintenance of the new social organization.

The hydrocarbon man era was characterized by a strong growth in global economy, the "golden age of capitalism"1 ${ }^{1}$ (1945-1973). Oil may be seen as a crucial catalyst of this period. Among the factors that contributed to such central role are its low prices in the 1950s and 1960s, as well as the expansion to new production frontiers, especially in the Middle East and Venezuela.

Even after the 1970s' crisis, the importance of oil was not shaken. Together, oil and natural gas, the two main products of the E\&P stage of the industry, represented $62 \%$ of the energy matrix in 1973 . Despite the multiple effects and initiatives in changing the energy industry, in 2010 such participation was still important, at $53.7 \%$, as shown in Graph 1 .

Graph 1: Primary supply of world energy (\%) - 1973-2009
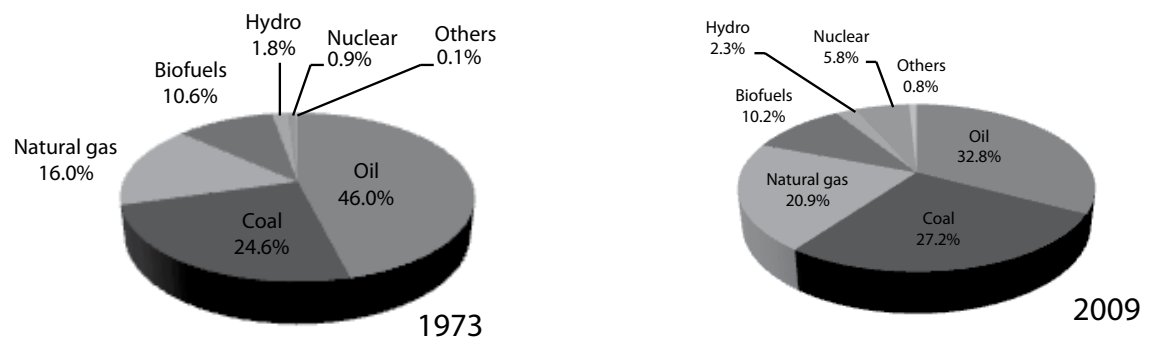

Source: IEA (2011).

If on the one hand the importance of oil to the national economies explains its strategic character, on the other the geographical dimension is indispensable in order to understand the characteristics of the diplomatic action in this industry. The uneven distribution of reserves is a crucial factor to understand this issue, mainly favoring the less important global consuming countries like in the Middle East, Africa and Latin America (BP, 2011).

Thus, there is a historical distinction between consuming and producing countries. In 1965, the greater part of production was concentrated in the Middle East and North America, which was ranked, together with the countries in Europe and Eurasia, as a major consumer. In 2010, there is a change in this division: all regions increased their production, especially Europe, Eurasia, Middle East and Africa. On the demand side, it is noteworthy the growth in consumption in Southeast Asia, mainly driven by the Chinese economy, which represented little more than one third of the oil demand in the region in 2010 (BP, 2011).

\footnotetext{
${ }^{1}$ The post-World War II period is named after the period of great economic prosperity, mainly in the West, which was over in the 1970s due to the rupture of the bases of the international system idealized in 1944 in the Bretton Woods Agreement (Belluzzo and Tavares, 2009).
} 


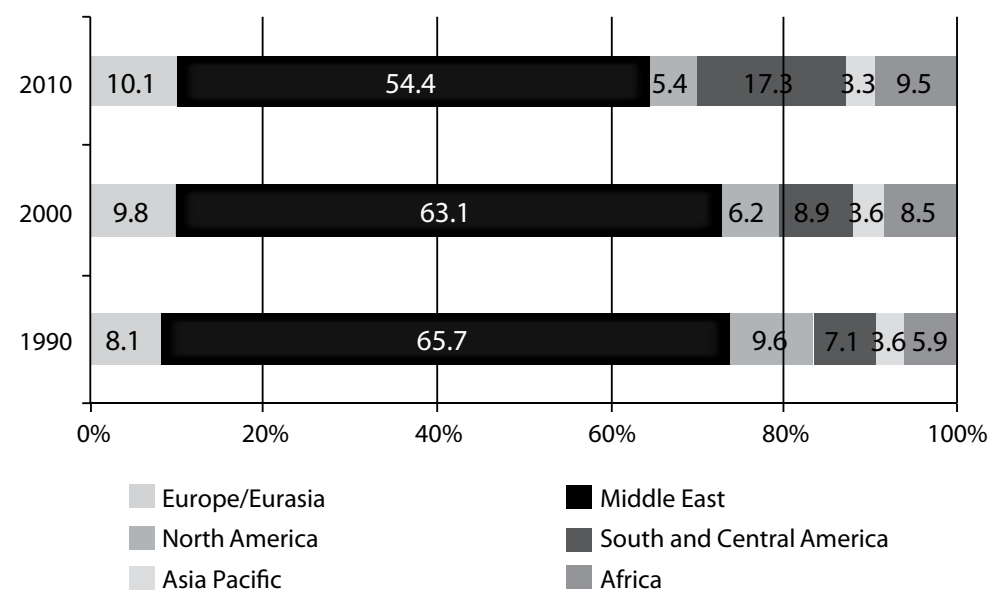

Source: BP (2011).

Even if the transformation of the participation of each region in total global proved reserves are important over time, broadly speaking it kept its uneven distribution. Historically, the rapid growth in demand that made oil occupy a central role in the global energy consumption, together with the distribution of reserves, explained the permanent gap between oil production and consumption in most of the regions, thus molding — in the post-war — an industry that is structurally linked to the international trade of the product.

From this point of view, it became imperative to grant the capacity of oil supply and its derivates to sustain the production and consuming structures in local economies. Such yearning for a stable supply thus converged with the military strategy to become what could be called "national security."

The uneven distribution of oil also yields an accumulation potential linked to the control of such resource. Additionally, the differences in terms of quality and volume of these reserves in various parts of the world causes different production costs, thus giving room to a dynamic of different economic income appropriations. A significant portion of the history of this industry may be reported based on the escalation of the dispute for the appropriation of such surpluses.

The control of the resources and the international flow of the product ${ }^{2}$ depend on the broad relationship of nation states and their diplomatic institutions. As a part of the constitution of such intricate web of relations and political and eco-

\footnotetext{
${ }^{2}$ The international trade of oil and natural gas represented $15 \%$ of all international transactions in 2010 (UNCTAD, 2011).
} 
nomic disputes around oil was the advent of various players, among which are the companies (private, state-owned and semi-state owned).

The consolidation of the oil industry as a complex geopolitical web is, therefore, strongly associated to the symbiotic condition between companies and nation states in an international dispute for the control of the generation and the appropriation of this industry's wealth. In other words, the influence of the nation states is a must aiming at the viability and institutional safety of these investment flows and their subsequent surplus appropriation.

Thus, in order to understand the dynamics of this web, it is necessary to analyze more carefully the companies involved and their historical trend.

\section{Historical evolution of the global oil industry players}

The growth of the oil industry, of the size of the markets and of the exploration and refining initiatives in a global scale allowed the emergence of large, sophisticated and internationalized companies over time. The financial size of these groups made them players in the process of capital valuation higher than most of the other industries in the productive side of the economy. Furthermore, the consolidation of this process depends on an international productive chain that involves various countries.

The history of this industry's players begins at the end of the $19^{\text {th }}$ century and the beginning of the $20^{\text {th }}$, when Standard Oil Company consolidated itself as the largest oil company in the world, taking advantages of economies of scale and vertical integration, from upstream to downstream ${ }^{3}$ (Yergin, 1991). After the breaking of the monopoly, resulting from the 1911 American antitrust law, smaller groups were established. Together with the large European companies in this market, they gave rise to the "Seven Sisters", transnational oil companies that dominated the market until the 1960s.

As this industry is capital intensive, the gains in scale, and the size of the groups, became central elements in the determination of their competitive advantages (Valente, 2009). Having access to reserves that are easy to extract and with a superior quality, together with closeness to the final markets, became a strategic goal.

The establishment of companies around a verticalized structure, which are influential in the definition of technological regimes and historical pioneers, allowed the accumulation of resources and capabilities essential to the companies in central countries, making them the process leaders. By considering the economic size of the companies, Table 2 allows the evaluation of the dimension of the valuation process behind this resource.

\footnotetext{
${ }^{3}$ Upstream is made of the activities of exploration and production (E\&P) of oil and natural gas (E\&P). Downstream consists of transportation, refining and distribution of derivates. In this period, the control of transportation and refining became particularly important for leading the industry.
} 
Table 2: Revenues and net income of the largest oil and gas companies (in US\$ billions) - 2013

\begin{tabular}{|c|l|c|c|}
\hline \multicolumn{2}{|c|}{ Company } & Revenues & Net Income \\
\hline 1 & Royal Dutch Shell & 481.7 & 26.6 \\
\hline 3 & Exxon Mobil & 449.9 & 44.9 \\
\hline 4 & Sinopec Group & 428.2 & 8.2 \\
\hline 5 & China National Petroleum & 408.6 & 18.2 \\
\hline 6 & BP & 388.3 & 11.6 \\
\hline 10 & Total & 234.3 & 13.7 \\
\hline 11 & Chevron & 233.9 & 26.2 \\
\hline 17 & ENI & 167.9 & 10.0 \\
\hline 21 & Gazprom & 153.5 & 38.1 \\
\hline 25 & Petrobras & 144.1 & 11.0 \\
\hline 36 & Pemex & 125.2 & 0.2 \\
\hline 38 & PDVSA & 124.5 & 2.7 \\
\hline 39 & Statoil & 124.4 & 11.8 \\
\hline 46 & Lukoil & 116.3 & 11.0 \\
\hline
\end{tabular}

Source: Own elaboration based on data from the Global 500 Fortune Ranking (2013).

Clearly, the oil companies have an outstanding ranking within the group of the 50 largest companies in the world. Besides the size of the companies, the industry allows a chaining effect with other steps in the productive chain, like equipment and services supply, as well as efficiency towards the consuming sectors. Accordingly, the profits arising from the oil produce a large capital mobility, which flow is crucial for the unending expansion of the global financial capital structure, and the related banking interests (Gowan, 2003). As already mentioned, the influence of the nation states is indispensible for the institutional viability of these investment flows and surplus appropriation.

Following the disputes of national interests, the evolution of the industry's capital structure changed throughout its historical cycles. Torres Filho (2004) lists three organizing standards of the international market, thus of the own geopolitics of global oil. In the first phase (1945-1973), there was the consolidation of the hegemony of the Unites States in the Middle East, with a substantive increase in investment and accumulation of the "Seven Sisters".

In this context, the stable development of production - to prevent predatory price wars - was dependent on two conditions: the definition of property rights over the Middle East reserves, and the adoption of an oligopolistic configuration to grant supply for the demand. These steps were taken via a system of concessions or consortiums (or associations) (Pinto Jr., 2007).

According to the concession system, the companies were granted some sort of 
absolute right to prospect, extract and sell oil in a certain territory under jurisdiction of a host nation state in exchange of financial compensation. Thus, there was a regulation of the relations between the government of oil producing countries and the international companies (using the fifty-fifty concession), granting an ample power to the oil industry.

The consortiums, on the other hand, were the foremost mean to regulate the formal relations among companies. By defining the adequacy and mechanism of joint management as a means to prevent competition, the consortiums also led to the setting up of the international cartel. Thus, by dividing the global markets, the big companies strengthened their positions through an informal deal about the fixing of production quotas, prices and the control of the conditions of new entrants.

As already mentioned in the previous section, this power configuration led to stability in the post-war period, when there was the peak of the economic growth of the United States. It was followed by the central and peripheral countries, with their national industrialization projects, together with a higher urbanization that demanded more oil.

In the 1960s, with the creation of the Organization of the Petroleum Exporting Countries (OPEC) $)^{4}$, the hegemony of the US and of the Seven Sisters was challenged. It is noteworthy that in that period the US became, for the first time, importer of oil. However, the tone of such movement was the various revisions of concession contracts in the Middle East during the 1970s, together with a wave of nationalizations in many countries of the region. With the change in these contracts, the postwar order was destabilized.

The second phase of the configuration of this market, between 1973 and 1985, was marked by the emergence of oil as an explicitly conflicting issue in international relations. In this context, the OPEC established itself not only as an economic organization, but also as a political instrument, capable of exerting bargaining power and impose new principles to the alliance system between the US and the countries in that region.

The relative scarcity of oil itself, together with its price rise, led to the establishment and gradual strengthening of new companies, as long as they had preferential access to reserves. Among these companies, called "state owned", we may highlight the ones from the OPEC countries themselves, but also the Norwegian, Argentine, Mexican, and Brazilian, among others. Part of them, like Petrobras, acted as gobetween of the import activity and the granting of domestic supply, as a consuming

\footnotetext{
${ }^{4}$ The Organization of the Petroleum Exporting Countries was created in 1960 as a response to the specific political demands for the unification of the oil policies among its members, aiming at controlling the production and distribution of oil, thus granting its international prices. It currently includes 12 countries, owners of some of the largest oil reserves in the world: Angola, Algeria, Libya, Nigeria, Venezuela, Ecuador, Saudi Arabia, United Arab Emirates, Iran, Iraq, Kuwait, and Qatar.
} 
country company ${ }^{5}$, but also as the instrument of a project of active insertion in the oil chain, of energetic independence and of the diversification and strengthening of the productive sector.

Because of all of these elements, the establishment of these companies was vital to the advance of the producing countries' projects. Initially linked only to their own countries, they gradually reorganized the international dispute for the wealth generated in the industry and, in various intensity, made local technologies feasible, promoted the strengthening of their productive chain, the advance of national companies in the oil side industry, together with other measures associating strategies of national development to the oil industry.

A third moment of organization in the industry was between 1985 and 2002. The organization of oil supply, its demand for production, and the selling of oil derivates were no longer a prerogative internal to the companies. The financialization movement of the economy itself, and its capital markets expansion, led to the creation of a broad market for the trading of such "asset", both in spot and future markets. Such flexibility, together with the changes in OPEC's quota policy, is also associated with the decrease in oil prices after 1985, the so-called "oil countershock" (Torres Filho, 2004).

The industry era that began in 1985 also yielded a large equity movement, with results after 2002. In two periods, 1998-2001 and 2005-2008, there was an intense process of mergers and acquisitions (M\&A), which caused such a concentration of capital to allow the emergence of the so-called mega majors, partly derived from the former Seven Sisters (Valente, 2009). Part of this M\&A activity also took place under the leadership of growing or state owned companies like Statoil or Petrobras. In the case of the Brazilian company, the acquisition of the assets of Argentine Perez Companc allowed an ample international repositioning of the company, allowing new strategies in upstream and downstream areas, especially in South America. It also worked as a new political instrument in the Brazilian regionalization strategy, which most important evidence is the gas pipeline Bolivia-Brazil (Gasbol).

The already mentioned equity shift of the 1990s is associated by Valente (2009) to the production valuation cycles of this industry, led by the changes in market prices and the performance of companies he called "progressive" (or with a higher potential for accumulation). Evidently, this reading should come together with that of the political processes of the weakening of nation states and the advance of the ideology in favor of the process of the privatization of the energetic industry.

As a matter of fact, the historical evolution of the oil industry led to the sprouting of a myriad of companies, with various nationalities and profiles of sector inser-

\footnotetext{
${ }^{5}$ The pioneering internationalization projects of Petrobras, which even include participations in the Middle East had, in a different scale, similar national objectives to the ones of the large transnational companies: a favorable positioning as far as reserves are concerned, the increase in accumulation, and the response to the energy demand of its own country.
} 
tion, and with technological, investment and accumulation capabilities. However, among the companies that de facto lead industry trends, either in technology or in aspects associated to its dynamics and investment volumes, two generic groups jump to the eye: the majors, called International Oil Companies (IOCs), and the state owned companies, called National Oil Companies (NOCs). The first group includes the large oil conglomerates, which came from the above-mentioned process of large mergers; the second comprises the state owned ones, normally associated with producing countries, in a heterogeneous group that also includes the semi-state owned ones.

Since the 1970s, the NOCs developed as agents of the producing nation-states to control the oil industry, and became an important instrument for the gains associated to the "energy nationalism" of their countries, controlling their revenues, investment or industrial policy. As highlighted by Jaffe and Soligo (2007), the NOCs also fulfill geopolitical and strategic goals of their governments, and are not only business oriented. Yet, it is noteworthy that the NOCs are still companies, thus subject to corporate logic. Although these two goals normally go hand in hand, one should not ignore that there may be occasional strategic incompatibilities.

Generally, such corporate logic is stronger in the subgroup of NOCS established as public companies with state control. This group is made of the companies that are semi-state owned - like Petrobras, Statoil, together with Chinese and Russian companies (PIW, 2010). Thus, most of the strategic control remains in the hands of the state, but the market practices and the concern with governance are a little higher than those of traditional state owned companies ${ }^{6}$.

Hence, it may be said that the current structure of the oil industry resource distribution derives from the movements that began in the 1970s. The state owned companies linked to the producing nation states, although still missing technological expertise, internationalization capabilities, and access to central markets like the IOCs, own abundant reserves.

The advantages of such access were decisive for the NOCs to be able to increase their capacity of accumulation and growth, especially in oil price rise moments. The semi-state owned companies, on the other hand, increased their operational efficiency and funding access. They gradually manifested the technological capabilities and R\&D investment similar to the IOCs', though such trace was not necessarily related to their equity profile. It is noteworthy that part of them also has a facilitated access to large reserves, which may reduce their E\&P investment cost. The Petrobras case is very peculiar because it historically invested, with success, in technological and operational capacity associated with one of the frontiers that turned out to be the most important to the upstream evolution of the industry.

\footnotetext{
${ }^{6}$ Using the PIW ranking, which is based on reserves control and production, it is clear that among the 20 most important companies in the industry, 9 are 100\% state owned (Saudi Aramco, NIOC, PDV, CNPC, Pemex, KPC, Sonatrach, Petronas e Adnoc); 7 are IOCs, without any state capitalization (Exxon Mobil, BP, Royal Dutch Shell, ConocoPhillips, Chevron, Total e Lukoil); and the remaining are semistate owned (Gazprom, Petrobras, Rosneft e ENI).
} 
It became clear, in this overall scenario, the historical strengthening of the NOCs and of the semi-state owned companies, which were altogether, at the end of the decade (2008), responsible for $61.7 \%$ of the produced volume and for $78.2 \%$ of the global oil proven reserves (Valente, 2009).

Such strengthening may also be seen in Graph 3, which shows their participation in total investment for each region's E\&P.

\section{Graph 3: International investments in E\&P by region (in \%) - 2012}

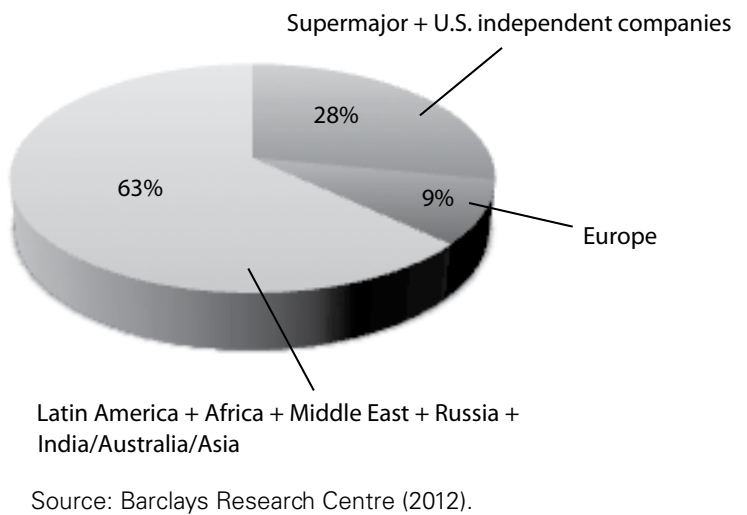

In Graph 3, their are divided in three categories: (i) the joint effort of the super majors and of the independent North-American companies, normally private enterprises; (ii) the European companies, with diversified equity structures, either state owned, private and semi-state owned; and (iii) the Latin American, African, Middle Eastern, Russian, Indian, Asian and Australian mostly state owned companies. It is noteworthy that the group controlled by the NOCs is responsible for the larger part $(63 \%)$ of the E\&P investments for 2012.

Actually, the equity structure changes in the oil industry are hand in hand with the evolution of the supporting regulatory marks and contractual instruments of the markets since the 1970s. Together with the reserves nationalization of that decade, there was a substitution of the concessions by long term buying and selling contracts, which promoted a better balance in the supply and demand balance.

In summary, the importance of the peripheral countries' companies evolved after the World War II, when various countries adopted new strategies for the development and control over natural resources. In the oil industry, in general, such moves were the result of the reaction to the control of the multinationals, or in search for a higher capacity of national development. Thus, what turned out to be called "energy nationalism", in part of the literature, could be seen in Venezuela right after the World War II, but also in Brazil, Argentina, Ecuador, and in African and Asian countries.

So, the oil companies gradually stopped to be only the instrument of the project of the internationalization and transnationalization of the power relations in 
the central countries. The emergence and strengthening of the NOCs paved the way for the exercise of the political power by the producing countries. Such companies began to establish and operate themselves, just the same as in the central countries, as instruments of capital valuation, industrial development and energetic security.

Finally, the characterization of energy nationalism in the oil industry implies that this energetic source is a special commodity, subject to power relations. The main players are large-scale economic agents, able to influence the direction and rhythm of economic growth and development. Therefore, any study aiming at contributing to this subject should contemplate the complexities of the relationship among nation states (either producing or consuming), and the state owned, semistate owned and private companies. The shape of such relations changed throughout the political and economical cycles of the industry itself, promoting both institutional changes and in the accumulation conditions. The following section summarizes the approach of this study, using the positive aspects present in the literature, as well the structural elements presented so far.

\section{FINAL CONSIDERATIONS}

Based on a historical-structural analysis, "energy nationalism" is understood, in this study, in its two dimensions related to the national interest of the nation states' energy industry. Firstly, it has to do with the maintenance of energetic security. Such dimension encompasses the granting of energy stability for military use, industrial development, and the evolution of the growth standard of a society founded on the consumption of such energy, together with other products from the petrochemical industry. Secondly, it is about the dynamics of accumulation and appropriation of the wealth generated in the industry by national players, possible either via the taxation system (state appropriation), or the performance of national oil companies (business appropriation).

When understood in line with these two dimensions, energy nationalism does not have to be only associated to the producing countries. Under this prism, both the consuming and producing countries structurally exert energy nationalism, even if they use various combinations of instruments. Thus, the dispute in the industry may be understood as a "bargain". However, together with the dispute between producing states and oil companies, this quarrel takes place between nation states and their companies (state owned or private), which look for increasing their energetic security and the appropriation of the wealth produced in the industry.

The dynamics among these players, whether they are nation states, state owned, semi-state owned or international companies, is regulated by institutions based on rules that define which ones may operate in certain segments/regions, as well as under which conditions they will accumulate, appropriate and distribute the generated energy and wealth. The regulatory marks are, therefore, the result of this bargaining in each producing region, subject to historical changes.

In other words, the political and institutional arrangements out of which come 
the changes in rules and property rights are commonly changeable so that energy nationalism is also subject to historical cycles.

The dynamics of each of the energy nationalism cycles is influenced by endogenous and exogenous factors to the industry. Such elements are responsible for granting a stronger or weaker "bargaining power" to the countries (and their companies) in the correlation of forces and in the capacity to influence favorably the institutions and the market dynamics.

The exogenous factors able to influence such cycles may generally be attributed to political-ideological as well as general geo-economic drives, among which are the historical changes in the perception of the role of the state. Obviously, a lower state intervention favors the energy nationalism of the consuming countries, either by the reduction of the state appropriation of the producing countries, or by a higher financial and technological power of the large IOCs in the free market, together with the advance in privatization.

As far as this study is concerned, the growth contexts of the nationalistic movements also match the historical moments in which the development of the national industry occurs due to the participation of the state, in which the international conditions of markets control do no exclude the traditional instruments of national development.

On the other hand, the endogenous factors that influence the historical cycles of energy nationalism are the volatility of international oil prices and the conditions of access to reserves. The evolution of such factors can cause changes in the bargaining power of nation states and companies, thus defining contracts and strategies.

Broadly speaking, the discovery of large reserves in a specific territory affects its global participation. Such condition is stronger whenever there is a shortage of resources or when there is an ongoing increase in investments. The definition of the price level, also subject to this reserves dynamics, equally points to the changes in the conditions of energy nationalism performance.

Thus, in most of the cases, an increase in prices intensify nationalism in the producing countries and, on the other hand, lower prices favor consumers and their oil companies. The reserves have a similar impact. A market with a shortage in supply favors countries with more resources. The abundance of supply, on the other hand, favors the practice of energy nationalism in the consuming countries.

In summary, energy nationalism may be understood as a permanent dispute between nation states and companies, between producing and consuming countries, aiming at granting the energy supply and the appropriation of the wealth generated by the industry. The changes in power relations, whenever promoting inadequate mainstream regulatory marks, historically lead to its reorganization. Thus, the study of energy nationalism contributes to the characterization of the oil industry, of the international relations in this industry, as well as the recurring politicalinstitutional changes and historical cycles in this industry. 


\section{REFERENCES}

ARMENTANO, D. T. (1981). “The Petroleum Industry: a historical study in power”. Cato Journal, v. 1, n.1.

BARBIERI, R. (2011). Energy Security: the diplomacy of South Korea in Latin America. UCLA Center for Korean Studies. Los Angeles, California, USA. http://www.international.ucla.edu/media/files/ Rita_Barbieri_SRG-h3-4zo.pdf. Accessed 26 February 2014.

BARCLAYS - Global E\&P Capital Spending Update (2012). Accessed 24 February 2014: http://www. oilandgas360.com/analytics/BARCLAYS_EP_SPENDING_UP_103011174.pdf.

BELLUZZO, L. G.; TAVARES, M. C. (2009). “Capital financeiro e empresa multinacional”. In: BELLUZZO, L. G. Os Antecedentes da Tormenta: origens da crise global. Campinas: UNESP.

BP — BRITISH PETROLEUM (2011). "Statistical Review of World Energy 2011”. http://www.bp. com/content/dam/bp/excel/Statistical-Review/statistical_review_of_world_energy_2013_workbook.xlsx. Accessed 26 December 2013.

FORTUNE GLOBAL 500 (2013). Annual ranking of the world's largest corporations. Accessed 2 November 2013: http://money.cnn.com/magazines/fortune/global500/2013/full_list/index.html.

GOWAN, P. (2003). A roleta global: uma aposta faustiana de Washington para a dominação do mundo. Rio de Janeiro: Record.

HOBSBAWM, E. (1994). Era dos Extremos: o breve século XX (1914-1991). São Paulo: Companhia das Letras.

IEA — INTERNATIONAL ENERGY AGENCY (2011). “Key World Energy Statistics 2011”. http:// iea.org/publications/freepublications/publication/key_world_energy_stats-1.pdf. Accessed 02 January 2014.

ISBELL, P. (2009). Energy for the Hemisphere: reflections on the energy aspects of the draft Declaration of Commitment. FOCAL - Canadian Foundation for the Americas. http://www.focal.ca/ pdf/summitV_Isbell_IAD_energy\%20hemisphere_January\%2013\%202009_Washington.pdf. Accessed 30 January 2014.

MABRO, R. (2007). Oil Nationalism, the Oil Industry and Energy Security Concerns. Real Instituto Elcano. http://www.realinstitutoelcano.org/wps/portal/rielcano_in/Content?WCM_GLOBAL_ CONTEXT=/elcano/Elcano_in/Zonas_in/ARI114-2007. Accessed 30 January 2014.

NEWBERY, D. M. G. (1999 [2001]). Privatization, restructuring, and regulation of network utilities. 3 ed. Estados Unidos: The MIT Press.

PIW - PETROLEUM INTELLIGENCE WEEKLY (2010). PIW's top 50: how the firms stack up. http://www.highbeam.com/doc/1G1-244652753.html. Accessed 09 February 2014.

PINTO JR., H. Q. (org.) (2007). Economia da Energia: fundamentos econômicos, evolução histórica e organização industrial. Rio de Janeiro: Elsevier.

STEVENS, P. (2008). "National oil companies and international oil companies in the Middle East: under the shadow of government and the resource nationalism cycle". Journal of World Energy Law \& Business, 1(1): 5-30. http://jwelb.oxfordjournals.org/content/1/1/5.full. Accessed 30 January 2014.

TORRES FILHO, E. T. (2004 [2007]). “O Papel do Petróleo na Geopolítica Americana”. In: FIORI, José Luís (org.). O Poder Americano. 3 ed. Petrópolis, RJ: Vozes.

UNCTAD STAT - United Nations Conference on Trade and Development. Reports. http://unctadstat. unctad.org/ReportFolders/reportFolders.aspx. Accessed 2 February 2014.

VALENTE, F. (2009). A dinâmica da acumulação de capital e os movimentos de fusões e aquisições em estruturas de mercado oligopolísticas: um estudo focado na evolução recente da indústria mundial do petróleo. Dissertação (Mestrado em Ciências Econômicas) — Instituto de Economia, Universidade Estadual de Campinas, Campinas, SP.

YERGIN, D. (1991 [2012]). O petróleo: uma história mundial de conquistas, poder e dinheiro. $1^{\mathrm{a}}$ reimpressão. São Paulo: Paz e Terra. 